\title{
Analysis of the Accident Rate of the Constituent Entities of the Russian Federation
}

\author{
A. G. Shevtsova ${ }^{1}{ }^{*}, V . V$. Vasilieva $^{2}, A . G$. Burlutskaya ${ }^{1}, K . V$. Levshina $^{2}$, and E. M. Minaeva ${ }^{2}$ \\ ${ }^{1}$ Belgorod State Technological University named after V.G. Shukhov, Belgorod, Russia \\ ${ }^{2}$ Orel State University named after I.S. Turgenev, Orel, Russia
}

\begin{abstract}
Every year, tens of thousands of road traffic accidents occur on the territory of Russia, characterized by different accident rates. Some of the most common are road traffic accidents, in the place of which violations of the mandatory requirements for the operational state of highways and railway crossings have been recorded under the conditions of ensuring road safety. The condition of the asphalt concrete road surface affects the grip performance of the vehicle with the road. It is necessary to study the statistics of road traffic accidents in the constituent entities of the Russian Federation located in different road and climatic zones in order to determine the dependence and the degree of influence of the state of the road surface on the number of accidents occurring.
\end{abstract}

\section{Introduction}

In the Russian Federation, as in many other countries, transport is a large basic industry, an important component of the production and social infrastructure. Transport plays an important role in the socio-economic development of the country. Transport lines connect all regions of the country, defining its territorial integrity and economic space, as well as connecting the country with other countries, ensuring foreign economic relations between Russia and the countries of the world.

About 164,141 thousand road traffic accidents (RTA) occur annually in the Russian Federation, as a result of which 18,149 thousand people die. Over the past 5 years, 820701 thousand road accidents have occurred in the Russian Federation, in which 90743 thousand people died and 846284 thousand people were injured.

The state takes all possible measures to improve traffic and reduce the number of road accidents, developing projects and guided by the experience of foreign countries $[1,2]$. One of the most successful examples of this experience is the Swedish concept of safety Vision Zero «Concept of zero mortality», the purpose of which is to influence the statistics of deaths and injuries [3-5]. In Russia, the basic project is the project «Transport strategy of the Russian Federation for the period up to 2030 », one of the main goals is to achieve zero mortality by 2030 .

\footnotetext{
*Corresponding author: shevcova-anastasiya@mail.ru
} 


\section{Evaluation of statistics}

Based on the available official statistics of the website of the State Traffic Inspectorate, the accident rates in the Russian Federation were considered for the last 5 years from 2016 to 2020.The number of accidents that occurred during this period of time are presented in fig. 1 .

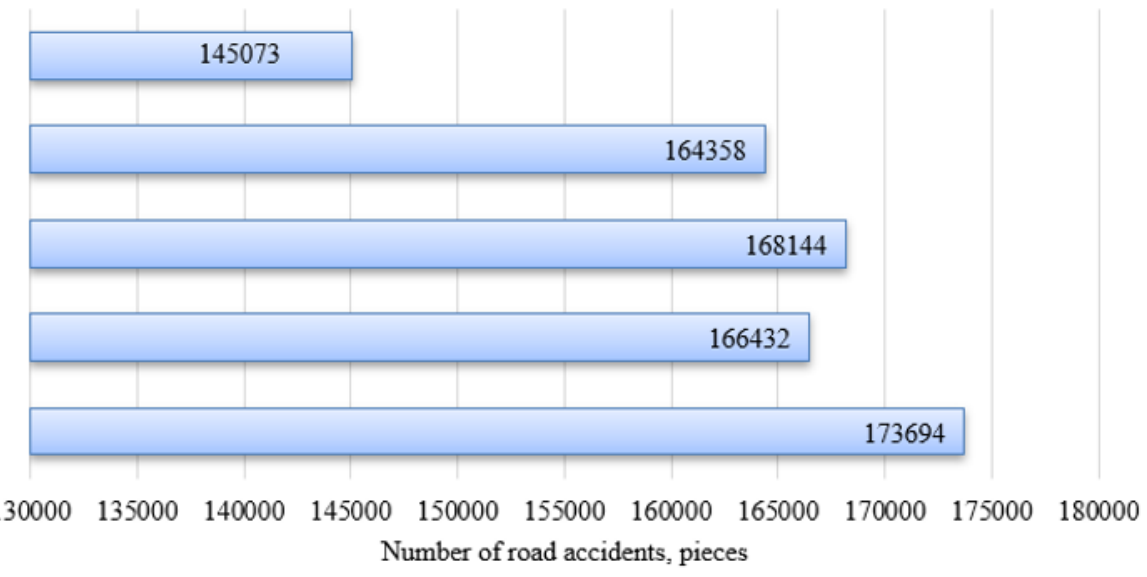

Fig. 1. Statistics of road traffic accidents in Russia for the period from 2016 to 2020

Having studied and analyzed the official statistics on accidents in the Russian Federation, it was determined that about $36 \%$ of the total number of road accidents occur for the reason, definitely in the traffic police statistics as: "Accidents at the site of which violations of the mandatory requirements for the operational state of highways and railway crossings were recorded on the terms of road safety ". The main requirements for the operational condition of highways are: the carriageway of roads and streets, the pavement of sidewalks, pedestrian and bicycle paths, landing sites, stopping points, as well as the surface of dividing strips, shoulders and slopes of the roadbed must be clean, without foreign objects, without relationship to their arrangement. The surface of the carriageway must not have subsidence, potholes, or other damage that impedes the movement of vehicles at the speed permitted by the Road Traffic Regulations. In other words, this paragraph includes road accidents that occur due to the unsatisfactory condition of the road surface. In fig. 2 shows the ratio of the total number of accidents in the Russian Federation to the number of accidents caused by the unsatisfactory condition of the asphalt concrete pavement (red line).

Based on the available statistical data, the dependences of the considered indicators on time were obtained. 2016 was adopted as the base year, and the number of road accidents over the past 5 years was considered. The dependency diagram shows that the number of accidents is decreasing, but at the moment it is at a high level. Compared to 2016, the total number of accidents decreased from 173694 thousand to 145073 thousand accidents. The number of accidents due to the unsatisfactory condition of the road surface in 2016 amounted to 71,550 thousand, by 2020 . decreased to 48,879 thousand. As a study, we will analyze road accidents arising due to the unsatisfactory condition of the road surface in different constituent entities of the Russian Federation. It is necessary to study the statistics of road accidents in the constituent entities of the Russian Federation located in different road and climatic zones in order to determine the dependence and degree of influence of the state of the road surface on the number of accidents occurring. 


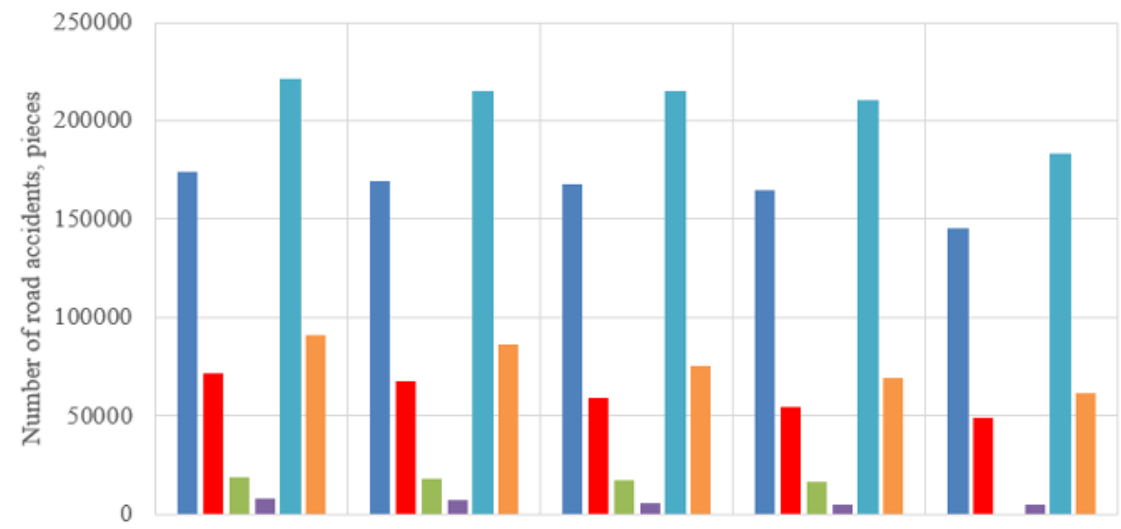

Fig. 2. Statistics of road accidents in the Russian Federation since 2016 by 2020 , caused by the unsatisfactory condition of the asphalt concrete pavement

\section{Determination of the significance of accidents in the constituent entities of the Russian Federation in terms of the unsatisfactory condition of the asphalt concrete pavement}

The length of roads in the Russian Federation is 1 million 396 thousand km. On the territory of the Russian Federation there are 85 equal subjects located in different climatic zones. The temperature range in which can vary from $-64^{\circ} \mathrm{C}$ to $+38^{\circ} \mathrm{C}[6]$. The amount of precipitation and the degree of moisture evaporation, the maximum and minimum temperatures, the rate of temperature fluctuations, the depth of soil freezing, the thickness of the snow cover, the duration of the frost period affect the conditions for the construction and operation of the road. It is necessary to select for the construction of highways such an asphalt-concrete mixture, which by its composition will be able to withstand all of the above climatic conditions, will be long-term and of high quality in use, and will also have high adhesion characteristics of vehicles with a road surface.

In accordance with the building codes and regulations in force in Russia (34.13330.2021 "Highways"), there are 5 road climatic zones (RCL) and a number of subzones. The first zone (I RCL) is characterized by permafrost soils. In this zone, permafrost soils prevent water seepage inward, therefore the upper layers of the soil are very wet. The second zone (II RCL) is a zone of excessive moisture, a zone of forests, due to a significant amount of precipitation and low evaporation, as well as a high level of groundwater. The third zone (III RCL) is a zone of significant moisture in certain periods of the year - in spring and autumn. The fourth zone (IV RCL) - the zone of insufficient moisture - the steppe. It is characterized by moderate moisture in the upper layers of the soil due to high evaporation and a small amount of precipitation. The fifth zone (V RCL) is an arid zone, which is characterized by slight moisture as a result of strong evaporation.

In order to draw a conclusion about how climatic conditions and the presence of a subject in one or another RCL affect the adhesion qualities of vehicles with the road, we will conduct a detailed analysis of the official statistics of the traffic police on road accidents of all subjects of the Russian Federation located in different RCL.

In the course of studying the statistics, one subject of the Russian Federation was determined, the number of accidents in which it has high rates for each road-climatic zone and its subzone. The largest number of road accidents occurred as a result of violations of the requirements for the operational state of highways, for 5 years in the period from 2016 to 2020. it was revealed: for the I RCL and its subzones - Murmansk region - 168 accidents, 
Irkutsk region - 447 accidents, Krasnoyarsk Territory - 234 accidents; II RCL - Leningrad Region and St. Petersburg - 1355 RTA, Moscow Region and Moscow - 1469 RTA, Nizhny Novgorod Region - 747 RTA; III RCL - Chelyabinsk Region - 1010 RTA, Omsk Region 858 RTA, Volgograd Region - 619 RTA; IV RCL - Samara region - 719 accidents, Saratov region - 680 accidents, Kemerovo region - 588 accidents; V RCL - Astrakhan region - 252 accidents, the Republic of Dagestan - 159 accidents and the Republic of Kalmykia - 62 accidents. More detailed statistics are presented in the table 1.

Table 1. Accident rate indicators of the constituent entities of the Russian Federation depending on the RCL

\begin{tabular}{|c|c|c|c|c|c|c|c|c|}
\hline \multirow[t]{2}{*}{ № } & \multirow{2}{*}{$\begin{array}{l}\text { Road } \\
\text { climatic } \\
\text { zones } \\
(\mathrm{RCL})\end{array}$} & \multirow[t]{2}{*}{ Territorial division } & \multicolumn{5}{|c|}{$\begin{array}{l}\text { The number of accidents at the site of } \\
\text { which violations of the mandatory } \\
\text { requirements for the operational state of } \\
\text { highways and railway crossings were } \\
\text { recorded under the terms of road safety }\end{array}$} & \multirow{2}{*}{$\begin{array}{c}\text { The } \\
\text { total } \\
\text { number } \\
\text { of } \\
\text { acciden } \\
\text { ts for } 5 \\
\text { years }\end{array}$} \\
\hline & & & $\begin{array}{c}201 \\
6\end{array}$ & 2017 & 2018 & 2019 & 2020 & \\
\hline \multicolumn{9}{|c|}{ I RCL } \\
\hline 1 & $\begin{array}{c}\mathrm{I}_{1} \\
\text { (northern } \\
\text { subzone) }\end{array}$ & Murmansk region & 38 & 33 & 37 & 22 & 38 & 168 \\
\hline 2 & $\begin{array}{c}\mathrm{I}_{3} \\
\text { (southern } \\
\text { subzone) } \\
\end{array}$ & Irkutsk region & 137 & 91 & 66 & 58 & 95 & 447 \\
\hline 3 & $\begin{array}{c}\mathrm{I}_{3} \\
\text { (southern } \\
\text { subzone) }\end{array}$ & Krasnoyarsk region & 28 & 50 & 33 & 41 & 22 & 234 \\
\hline & \multicolumn{8}{|c|}{ II RCL } \\
\hline 4 & $\begin{array}{c}\mathrm{II}_{1} \\
\text { (northern } \\
\text { subzone) }\end{array}$ & $\begin{array}{l}\text { Leningrad region and } \\
\text { St. Petersburg }\end{array}$ & 320 & 265 & 246 & 271 & 253 & 1355 \\
\hline 5 & $\begin{array}{l}\mathrm{II}_{2} \text { (central } \\
\text { subzone) }\end{array}$ & $\begin{array}{l}\text { Moscow region and } \\
\text { Moscow }\end{array}$ & 333 & 426 & 300 & 210 & 200 & 1469 \\
\hline 6 & $\begin{array}{l}\mathrm{II}_{2} \text { (central } \\
\text { subzone) }\end{array}$ & $\begin{array}{c}\text { Nizhny Novgorod } \\
\text { Region }\end{array}$ & 201 & 153 & 156 & 87 & 150 & 747 \\
\hline & \multicolumn{8}{|c|}{ III RCL } \\
\hline 7 & III & Chelyabinsk region & 218 & 234 & 182 & 191 & 185 & 1010 \\
\hline 8 & III & Omsk region & 174 & 160 & 156 & 193 & 175 & 858 \\
\hline 9 & III & Volgograd region & 120 & 134 & 137 & 111 & 117 & 619 \\
\hline & \multicolumn{8}{|c|}{ IV RCL } \\
\hline 10 & IV & Samara Region & 121 & 192 & 180 & 144 & 82 & 719 \\
\hline 11 & IV & Saratov region & 109 & 124 & 147 & 133 & 167 & 680 \\
\hline 12 & IV & Kemerovo region & 97 & 138 & 128 & 117 & 108 & 588 \\
\hline & \multicolumn{8}{|c|}{ V RCL } \\
\hline 13 & $\mathrm{~V}$ & Astrakhan region & 50 & 51 & 41 & 56 & 54 & 252 \\
\hline 14 & $\mathrm{~V}$ & Republic of Kalmykia & 12 & 13 & 9 & 18 & 11 & 62 \\
\hline 15 & $\mathrm{~V}$ & $\begin{array}{c}\text { The Republic of } \\
\text { Dagestan }\end{array}$ & 37 & 34 & 37 & 14 & 37 & 159 \\
\hline
\end{tabular}




\section{Conclusion}

Based on statistical data, the largest number of accidents arising from the unsatisfactory condition of the road surface occurs in II and III road climatic zones (RCL) in areas of excessive and significant moisture. The purpose of further research is to determine the degree of influence of a wetted road surface on the quality of adhesion of a car wheel to the road in these road-climatic zones and to assess a certain effect on the operation of equipment that controls traffic flows $[7,8]$.

Despite the reduction in the number of accidents, the number of road accidents remains high. It is necessary to continue to carry out not only the existing measures to reduce the growth of accidents, but also to develop new ways to solve this problem.

\section{References}

1. Kravchenko P.A., Vorobiev A.G. Organizational and technological resource for solving the problem of ensuring road safety in the Russian Federation // Transport of the Russian Federation. 2008. No. 2 (15). pp. 44-49.

2. Kravchenko P.A., Oleshchenko E.M. A systematic approach to road safety management in the Russian Federation // Transport of the Russian Federation. 2018. No. 2 (75). pp. 14-18.

3. Belin, M., Vedung, E., Tillgren, P., 2012. Vision Zero - a road safety policy innovation. // Int. J. Injury Control Saf. Promotion 19 (2), 171-179.

4. Belin, M., Tillgren, P., 2012. Vision Zero. How a policy innovation is dashed by interest conflicts, but may prevail in the end. // Scand. J. Public Administration 16 (3), 83-102

5. Kim, E., Muennig, P., Rosen, Z., 2017. Vision Zero as a toolkit for road safety. // Injury Epidemiol. 4 (1), 1-9.

6. Novikov A, Shevtsova A 2021 Development of an approach to determination of coupling qualities of road covering using weather-climate factor. Journal of Applied Engineering Science, 19(1) pp. 30 - 36.

7. Novikov A, Novikov I and Shevtsova A 2019 Modeling of traffic-light signalization depending on the quality of traffic flow in the city Journal of Applied Engineering Science Volume 17(2) pp. 175-181

8. Novikov A., Novikov I., Katunin A., Shevtsova A. Adaptation capacity of the traffic lights control system (TSCS) as to changing parameters of traffic flows within intellectual transport systems (ITS) / in the book: Transportation Research Procedia 2017. pp. 455-462. 